\title{
Uncovering The Myth Surrounding Cash Hoarding And Corporate Capital Expenditures Since 2008
}

Rakesh Duggal, Southeastern Louisiana University, USA Michael Craig Budden, Southeastern Louisiana University, USA

\begin{abstract}
If reports in the popular press are to be believed, even though the great recession of 2008 ended in 2009, U.S. corporate capital expenditures did not rebound. Lack of capital investment due to widespread cash hoarding is cited as a reason for the slow economic recovery. This study does not find evidence that $S \& P 500$ firms have slowed their rate of capital expenditures. On the contrary, capital intensive industries, such as materials, energy, and industrials show significant growth in capital expenditures in 2010 and 2011.
\end{abstract}

Keywords: Capital Expenditure; Wealth Maximization; Return on Investment; Cash Hoarding

\section{INTRODUCTION}

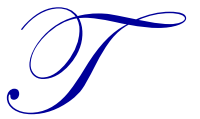

he shareholder wealth maximization objective requires that managers commit capital to only those projects that meet or exceed the firm's cost of capital. In efficient markets, the stock prices of companies announcing new capital outlays should reflect the positive/negative net present values of the outlays based on the investors' preliminary information on the outlays. McConnell and Muscarella (1985) report stock price increases for industrial firms announcing unexpected increases in capital expenditures, but not for utilities. Chung, Wright, and Charoenwong (1998) find similar evidence for companies with valuable investment opportunities. There is evidence that corporate capital investments by a firm even affect the stock prices of its competitors. Chen, Ho, and Shih (2007) find that rivals' share prices are more adversely affected when the investing firm experiences a higher announcement effect or is the first mover in the industry. Given those scenarios, the investment actions of firms given the recent economic downturn are of interest to many.

Press reports indicate that corporate capital expenditures are growing at an anemic rate and that U.S. firms are hoarding cash, resulting in a higher than normal unemployment rate (http://www.standardandpoors.com/ratings/articles/en/us/?articleType=HTML\&assetID=1245344777224). For instance, USA Today (2013) reports Google is hoarding some $\$ 48$ billion. Similarly, Apple has some $\$ 137$ billion in cash on its balance sheet (Swisher, 2013). Why are U.S. firms not investing if such investments, on average, are viewed positively by shareholders? There may be several explanations for the anemic corporate capital expenditures if the press reports are true. First, U.S. firms are unable to find positive NPV projects. This could be due to the excess capacity in the economy or, in certain industries, a slowdown in technological advances, and/or a low aggregate demand, in general, due to a severe shrinkage in wealth. Second, firms may face capital rationing. Lenders have become more cautious and are unwilling to lend on the more lax terms prevalent in the pre-2008 period. Further, as many have argued before, managers may be short-sighted and look for projects with a quick return. They have no patience for long-term projects that will dampen the company's results in the near future. Finally, it is possible that geo-political uncertainties complicate the managers' capital budgeting task. Fiscal cliff, looming currency wars, and global economic uncertainty make it difficult for managers to estimate either the cost of capital or the project's cash flows, resulting in lower capital expenditures.

On the other hand, just because some firms have large cash positions on their balance sheets, such positions don't translate directly into a non-investment strategy. Cash, besides its use to pay short-term obligations, offers 
firms the opportunity to make investments that may require substantial sums. In addition, there are myriad reasons for holding cash, including the desire to avoid US taxes by bringing the funds in from overseas activities.

This study attempts to answer two important research questions: 1) have corporate capital expenditures been growing at below "normal" rates in the post-recession period? And 2) if corporations have indeed not been investing, then what are corporations doing with the excess cash? Corporations may hoard cash, increase dividends, and/or buy back their stock if they are not investing.

\section{SAMPLE, DATA, AND STUDY DESIGN}

The study sample comprises all S\&P 500 firms, excluding the financials. Data on the 419 non-financial sample firms were gathered from Bloomberg Financial Services.

In order to determine the benchmark for the capital expenditure growth rate for each of the nine S\&P 500 industries, it is hypothesized that the capital expenditure growth rate is a function of the prior three years' sales growth rate. A number of prior studies have found corporate investments to be affected by CEO overconfidence (Malmendier and Tate, 2005) or by the firm's stock price (Polk and Sapienza, 2009). This study tried a number of variables to explain the capital expenditure growth rate, but the prior three-year sales growth rate appears to have the greatest explanatory power.

The 1998-2001 period is selected as the model estimation period in order to include the effect of a recession on corporate capital expenditures, as the U.S. economy experienced a recession in 2000. Using the panel data for each industry, a model is developed by regressing each firm's current year's capital expenditure growth rate on the previous three years' sales growth rate. Beginning in 2010, using the prior three years' sales growth rate for each firm, the industry model is used to predict the 2010 capital expenditure growth rate. The actual growth rate minus the predicted growth rate is defined as the abnormal growth rate. The abnormal capital expenditure growth rate is also estimated for 2011. Statistical tests are performed to determine if the corporate capital expenditures have grown at expected rates in the post-recession period.

\section{FINDINGS}

Table 1 contains regression parameters from regressing each firm's capital expenditure growth rate on the prior three years' sales growth rate during the period 1998-2001.

Table 1: Regression Parameters

\begin{tabular}{|c|c|c|c|}
\hline Industry & Intercept & Coefficient & F-Statistic (Probability) \\
\hline Energy & 3.162882 & 0.732648 & $\begin{array}{c}18.35292 \\
(0.00)\end{array}$ \\
\hline Materials & -6.21883 & 0.863539 & $\begin{array}{c}8.40845 \\
(0.00)\end{array}$ \\
\hline Industrials & -6.94878 & 0.807115 & $\begin{array}{c}48.55623 \\
(0.00)\end{array}$ \\
\hline Consumer Discretionary & -10.6168 & 1.781438 & $\begin{array}{c}126.1542 \\
(0.00)\end{array}$ \\
\hline Consumer Staples & 4.048261 & 0.692739 & $\begin{array}{c}9.066095 \\
(0.00)\end{array}$ \\
\hline Healthcare & 11.31842 & 0.533337 & $\begin{array}{c}38.31772 \\
(0.00)\end{array}$ \\
\hline Information Technology & -1.44714 & 1.039542 & $\begin{array}{c}58.50475 \\
(0.00) \\
\end{array}$ \\
\hline Telecommunications & -1.80658 & 0.281968 & $\begin{array}{c}0.939688 \\
(0.34)\end{array}$ \\
\hline Utilities & 16.82988 & 0.68671 & $\begin{array}{c}3.603636 \\
(0.06)\end{array}$ \\
\hline
\end{tabular}

Table Note: The OLS parameter estimates by industry were obtained from regressing a firm's capital expenditure growth rate on the preceding three-year sales growth rate. The sample includes all S\&P 500 firms, excluding the financial firms. The parameters were estimated using data from 1998 to 2001. 
The parameters are estimated for each industry to prevent industry-specific effects from diminishing the power of the statistical tests. As Table 1 indicates, the $\mathrm{F}$ statistic for the hypothesized relationship is highly significant in all but two industries - telecommunications and utilities.

In the next step, each firm's capital sales growth rate in 2010 (and 2011) is used in the industry model estimated in the previous step to predict the firm's capital expenditure growth rate. The predicted growth rate is subtracted from the actual rate to estimate the abnormal rate. t-Tests are performed to test the significance of the abnormal rates. Table 2 contains the findings.

Table 2: Excess Capital Expenditure Growth Rate By Industry For 2010 And 2011

\begin{tabular}{|l|c|c|}
\hline \multicolumn{1}{|c|}{ Industry } & $\begin{array}{c}\text { Actual Predicted Capital Expenditure } \\
\text { Growth Rate 2011 (Probability) }\end{array}$ & $\begin{array}{c}\text { Actual Predicted Capital Expenditure } \\
\text { Growth Rate 2010 (Probability) }\end{array}$ \\
\hline Energy & 35.41705484 & 11.40536 \\
& $(0.00)$ & $(0.07)$ \\
\hline Materials & 48.58270295 & 11.2422 \\
& $(0.00)$ & $(0.08)$ \\
\hline Industrials & 35.26429614 & 20.70216 \\
& $(0.00)$ & $(0.00)$ \\
\hline Consumer Discretionary & 28.69722473 & 28.85571 \\
& $(0.00)$ & $(0.00)$ \\
\hline Consumer Staples & 6.946091361 & 1.686856 \\
& $(.10)$ & $(0.64)$ \\
\hline Healthcare & 6.069497623 & 16.61512 \\
& $(0.17)$ & $(0.00)$ \\
\hline Information Technology & 11.18200809 & 8.974496 \\
& $(0.07)$ & $(0.33)$ \\
\hline Telecommunications & 49.50183322 & 27.79019 \\
& $(0.03)$ & $(0.10)$ \\
\hline Utilities & 6.51725198 & -17.8205 \\
\end{tabular}

The excess growth rate is defined as the actual rate minus the rate predicted by the model.

As column 3 of Table 2 indicates, "utilities" is the only industry that significantly reduced its capital expenditures in 2010. All remaining industries either display a significant increase in the capital structure growth rates or normal growth rates. In particular, healthcare, industrials, and consumer discretionary industries show highly significant and positive capital expenditure growth rates. In 2011, in addition to the industrials and consumer discretionary industries, energy, telecommunications and materials industries grew their expenditures significantly. 
The above evidence does not support the view that U.S. firms have not been investing at the expected levels. The study also statistically compares the mean values of capital expenditures, cash, common equity, and dividend payments in the pre-recession period (2005-2006) and the post-recession period (2010-2011). As Table 3 indicates, while energy and utilities significantly raised their capital expenditures, no significant changes are detected for the remaining industries.

Table 3: Changes In The Mean Values Of Capital Expenditure, Cash Balances, Par And Additional Paid In Capital, And Dividend Payments In The Pre-Recession (2005-2006) And Post- Recession (2010-2011) Periods

\begin{tabular}{|l|c|c|c|c|}
\hline \multicolumn{1}{|c|}{ Industry } & Capital Expenditure & Cash & Equity & Dividend Payments \\
\hline Energy & 1526.4565 & 247.3443 & 1635.0574 & -220.744 \\
& $(0.00)$ & $(0.64)$ & $(0.00)$ & $(0.00)$ \\
\hline Materials & 158.34308 & 753.1439 & 1127.2166 & -33.2261 \\
& $(0.10)$ & $(0.00)$ & $(0.06)$ & $(0.34)$ \\
\hline Industrials & -1.92721989 & 1762.358 & 543.08201 & -34.9858 \\
& $(0.80)$ & $(0.15)$ & $(0.05)$ & $(0.66)$ \\
\hline Consumer & -55.6409232 & 211.3912 & -4.535726 & -44.963 \\
Discretionary & $(0.53)$ & $(0.34)$ & 1154.0363 & $(0.39)$ \\
\hline Consumer Staples & 33.376902 & 430.8005 & $(0.01)$ & -239.263 \\
& $(0.71)$ & $(0.06)$ & 1362.5167 & $(0.07)$ \\
\hline Healthcare & 20.70647 & 1055.838 & $(0.08)$ & -167.658 \\
& $(0.43)$ & $(0.00)$ & 1447.3795 & $(0.00)$ \\
\hline Information & 204.70892 & 1021.621 & $(0.00)$ & -126.478 \\
Technology & $(0.05)$ & $(0.00)$ & 8319.0811 & $(0.06)$ \\
\hline Telecommunications & 1681.7486 & 1316.224 & $(0.11)$ & -1077.58 \\
& $(0.43)$ & $(0.29)$ & 930.01309 & $(0.25)$ \\
\hline Utilities & 648.64268 & 160.7944 & $(0.00)$ & -96.6327 \\
\end{tabular}

Probability values associated with the changes are provided in parentheses.

Materials, healthcare and information technologies raised their cash levels significantly while a number of industries, including materials, information technology, consumer staples, energy and utilities, raised new equity to beef up their balance sheets. Finally, dividend payments were reduced in all industries to conserve cash and/or to provide for capital expenditures.

\section{CONCLUSION}

Press reports indicate that U.S. firms have been holding back on capital expenditures and are responsible for the slow economic recovery and a high unemployment rate. Taking a sample of non-financial S\&P 500 firms and using regression analyses and mean tests, this study does not find evidence that U.S. firms have slowed down the capital expenditure growth rate. Evidence suggests that from 2005 to 2006 and 2010 to 2011, U.S. firms reduced their dividend payments, raised funds through new equity, and conserved cash while maintaining/increasing capital expenditures, in general.

\section{AUTHOR INFORMATION}

Dr. Rakesh Duggal is Professor of Finance at Southeastern. His research interests include corporate governance, capital structure, institutional investors and cost of capital. E-mail: rduggal@ selu.edu

Dr. Michael Craig Budden is the Candies Professor of Marketing at Southeastern. His research interests include intellectual property protection, ethics, business strategy and commercial law. E-mail: mbudden@selu.edu (Corresponding author)

\section{REFERENCES}

1. Chen, S., Ho, L., and Y. Shih, 2007, "Intra-industry effects of corporate capital investment announcements," Financial Management, volume 36, issue 2, 1-21. 
2. Chung, KH., P. Wright, and C. Charoenwong, 1998, " Investment opportunities and market reaction to capital expenditure decisions," Journal of Banking and Finance, volume 22, issue 1, 41-60.

3. Malmendier, U. and G. Tate, 2005, " CEO overconfidence and corporate investment," Journal of Finance, volume 60, issue 6, 2661-2700.

4. McConnell, J. and C. Muscarella, 1985, "Corporate capital expenditure decisions and the market value of the firm," Journal of Finance, volume 14, issue 3, 399-422.

5. Polk, C. and P. Sapienza, 2009, "The stock market and capital investment: A test of catering theory," Review of Financial Studies, volume 22, issue 1, 187-217.

6. Swisher, K. (2013, March 3). What could Apple buy with its $\$ 137$ billion? About 18 homes each for every Yahoo not to work at, and more. Retrieved March 3, 2013 from www.allthingsd.com/20130303/whatcould-apple-buy-with-its-137-billion-about-18-houses-each-for-every-for-every-yahoo-to-not-work-at-and$\underline{\text { more/ }}$

7. USA Today (2013, March 1). Google has \$48 billion cash hoard. Retrieved March 1, 2013 http://www.usatoday.com/story/money/business/2013/03/01/google-48-billion-dollar-cash-hoard/1957375/ 
NOTES 